\title{
A mouse model for triple-negative breast cancer tumor-initiating cells (TNBC-TICs) exhibits similar aggressive phenotype to the human disease
}

Punit Kaur ${ }^{1}$, Ganachari M Nagaraja ${ }^{1}$, Hongying Zheng ${ }^{1}$, Dawit Gizachew ${ }^{2}$, Moses Galukande ${ }^{3}$, Sunil Krishnan ${ }^{4}$ and Alexzander Asea ${ }^{1,5^{*}}$

\begin{abstract}
Background: Triple-negative breast cancer (TNBC) exhibit characteristics quite distinct from other kinds of breast cancer, presenting as an aggressive disease-recurring and metastasizing more often than other kinds of breast cancer, without tumor-specific treatment options and accounts for 15\% of all types of breast cancer with higher percentages in premenopausal African-American and Hispanic women. The reason for this aggressive phenotype is currently the focus of intensive research. However, progress is hampered by the lack of suitable TNBC cell model systems.

Methods: To understand the mechanistic basis for the aggressiveness of TNBC, we produced a stable TNBC cell line by sorting for $4 \mathrm{~T} 1$ cells that do not express the estrogen receptor (ER), progesterone receptor (PgR) or the gene for human epidermal growth factor receptor 2 (HER2). As a control, we produced a stable triple-positive breast cancer (TPBC) cell line by transfecting 4T1 cells with rat HER2, ER and PgR genes and sorted for cells with high expression of ER and PgR by flow cytometry and high expression of the HER2 gene by Western blot analysis.

Results: We isolated tumor-initiating cells (TICs) by sorting for CD24 $/$ CD $44^{\text {high }} / \mathrm{ALDH}^{+}{ }^{+}$cells from TNBC (TNBCTICS) and TPBC (TPBC-TICs) stable cell lines. Limiting dilution transplantation experiments revealed that CD24 ${ }^{+} / \mathrm{CD} 44^{\text {high }} / \mathrm{ALDH}^{+}{ }^{+}$cells derived from TNBC (TNBC-TICS) and TPBC (TPBC-TICS) were significantly more effective at repopulating the mammary glands of naiive female BALB/C mice than $\mathrm{CD} 24^{-} / \mathrm{CD} 44^{-} / \mathrm{ALDH1}^{-}$cells. Implantation of the TNBC-TICs resulted in significantly larger tumors, which metastasized to the lungs to a significantly greater extent than TNBC, TPBC-TICS, TPBC or parental 4T1 cells. We further demonstrated that the increased aggressiveness of TNBC-TICS correlates with the presence of high levels of mouse twenty-five kDa heat shock protein (Hsp25/mouse HspB1) and seventy-two kDa heat shock protein (Hsp72/HspA1A).
\end{abstract}

Conclusions: Taken together, we have developed a TNBC-TICs model system based on the 4T1 cells which is a very useful metastasis model with the advantage of being able to be transplanted into immune competent recipients. Our data demonstrates that the TNBC-TICs model system could be a useful tool for studies on the pathogenesis and therapeutic treatment for TNBC.

Keywords: Triple-negative breast cancer, Mouse and human HspB1, Hsp25, Hsp27, Hsp72/HspA1A, Heat shock, Cancer stem cells, Tumor-initiating cells

\footnotetext{
* Correspondence: asea@medicine.tamhsc.edu

'Department of Pathology, Scott \& White Memorial Hospital and Clinic and the Texas A\&M Health Science Center, College of Medicine, Temple, TX

76504, USA

Full list of author information is available at the end of the article
} 


\section{Background}

Triple-negative breast cancer (TNBC) is characterized by a lack of receptor expression of estrogen receptor (ER) and progesterone receptor (PgR) and lack of gene expression for human epidermal growth factor receptor 2 (HER2) [1,2]. Chemotherapy remains the only possible therapeutic option in the adjuvant or metastatic setting in the TNBC. Importantly, the prognostic effect of TNBC is independent of poor grade, nodal status, tumor size and treatment [3]. The aggressiveness of TNBC is further indicated by the fact that: (i) the peak risk of recurrence occurs within the first 3 years after initial treatment of the disease with the majority of deaths occurring in the first 5 years [4] and (ii) after diagnosis of metastatic disease, a significantly shorter survival is observed in TNBC [4]. Conversely, the risk for late recurrences (i.e. beyond 5 years of diagnosis) is decreased by $50 \%$ compared with HER2-positive disease [5]. More than 90\% of TNBC exhibit an invasive ductal histology and high histological grade, present with high mitotic index and carry central necrotic zones and pushing borders as well as a conspicuous lymphocytic infiltrate.

TNBC are typically observed in young African-American women, Hispanic women and Caucasian women who carry a mutation in the breast cancer 1 (BRCA1) early onset gene [6]. While some TNBC respond to chemotherapy, subsets of TNBC are chemotherapy-resistant and highly metastatic carrying with it an extremely poor prognosis [6]. The molecular mechanism, which governs the aggressive behavior of this subset of TNBC, is a matter of intense speculation, particularly since TNBC frequently express markers of epithelial mesenchymal transition (EMT). EMT is a normal developmental process in which cells of epithelial origin lose epithelial characteristics and polarity and acquire a mesenchymal phenotype associated with increased migratory behavior $[7,8]$.

Self-renewing cancer cells are reported to be the only cell types within a tumor with an unlimited ability to initiate tumor growth and are therefore known as tumor-initiating cells (TICs), cancer stem cells or tumor-propagating cells [9-11]. The majority of carcinoma cells express a CD $44^{\text {low }} / \mathrm{CD} 24^{\text {high }}$ phenotype; however, a small subpopulation of carcinoma cells present within human breast cancers that exhibit a CD $44^{\text {high }}$ / CD24 ${ }^{\text {low }}$ antigenic phenotype are highly enriched for TICs [12]. TNBC have been reported to have a higher percentage of CD $44^{\text {high }} / C D 24^{\text {low }}$ expressing cells than other breast cancer subtypes [13].

The mouse twenty-five $\mathrm{kDa}$ heat shock protein (Hsp25/ mouse HspB1) belongs to the family of small HSP and is the murine homologue of human twenty-seven $\mathrm{kDa}$ heat shock protein (Hsp27/human HspB1) which operates through ATP-independent mechanisms $[14,15]$. Elevated human HspB1 levels have been found in various tumors, including breast, prostate, gastric, uterine, ovarian, head and neck, and tumors arising from the nervous system and urinary system. Elevated levels of human HspB1 in ER- $\alpha$ positive benign neoplasia have been shown to promote the progression to more malignant phenotypes [16], increased anchorage independent tumor growth [17], increased resistance to chemotherapeutic drugs (including cisplatin and doxorubicin) and increased metastatic potential in vitro [18-20]. Furthermore, elevated human $\mathrm{HspB} 1$ expression in tumors correlated with shorter disease-free survival and recurrence in node-negative breast cancer $[21,22]$, whereas its induction following chemotherapy also predicted poor prognosis and shorter disease-free survival [23].

Surface bound/expressed and total Hsp25 (mouse HspB1) and Hsp72 (HspA1A) on 4T1 murine breast adenocarcinoma tumors suggest that tumor development and metastatic spread favors cells that express high levels of mouse HspB1 on their plasma surface. However, tumors that express Hsp72/HspA1A on their plasma surface are sensitive to anti-tumor effector cells, which indicate increased surface expression of Hsp72/HspA1A on tumors and down regulation of human HspB1 expression could inhibit tumor growth and eliminate metastasis $[24,25]$. Enhanced expression of intracellular Hsp72/ HspA1A has shown to be anti-inflammatory [26], antiapoptotic [18], induce cell cycle arrest [27] and protect cells from stressful stimuli [28]. In contrast, enhanced extracellular expression of Hsp72/HspA1A either on the surface of tumors or in the extracellular milieu either enhances natural killer (NK) cell-mediated lysis [29] or upregulates antigen presenting cells (APC)-mediated acute phase responses [30-33], respectively. A study in which the mouse $h s p b 1$ gene has been silenced using interference ribonucleic acid (RNAi) technology suggests that mouse HspB1 has a profound effect on tumor proliferation and migration [24,25].

In this study, we constructed TNBC and TPBC by the stable transfection of parental 4T1 cells with the rat HER2, ER and PgR genes and sorted for cells with high expression of HER2, ER and PgR. We further produced TNBC-TICs and TPBC-TICs by sorting CD24 ${ }^{+} / \mathrm{CD} 44^{\text {high }} /$ aldehyde dehydrogenase $1(\mathrm{ALDH} 1)^{+}$expressing cells from TNBC and TPBC. Functional analysis demonstrated that TNBC-TICs exhibits a more aggressive phenotype than TNBC, TPBC, TPBC-TICs or parental 4T1 cells. Taken together, our studies suggest that these cells could be important preclinical model to characterize and effectively target cancer stem cells or TICs, and to further our understanding of the aggressive nature of TNBC found in humans. 


\section{Methods}

\section{Cells and culture conditions}

4T1, a highly metastatic breast cancer cell line derived from a spontaneously arising BALB/c mammary tumor were purchased from American Type Culture Collection (ATCC; Rockville, MD). 4T1 cells were maintained in monolayer cultures in Dulbecco's modified Eagle's medium (DMEM) (Sigma Chemical, St. Louis, MO) supplemented with $10 \%$ fetal bovine serum (FBS). Cells were maintained at $37^{\circ} \mathrm{C}$ humidified atmosphere with $5 \% \mathrm{CO}_{2}$.

\section{Animals and tumor challenge}

Female BALB/c ( $\left.\mathrm{H} 2^{\mathrm{d}}\right)$ wild type mice (6-8 weeks old) were purchased from Charles River Laboratories (Wilmington, MA) and housed under pathogen-free conditions in laminar flow isolation units in the Scott \& White Hospital vivarium under alternate dark and light cycles, and maintained on food and water ad libitum. Female BALB/c (6-8 weeks old) were lightly anesthetized and the fur was shaved over the lateral thorax and a 5-mm-long incision was made to reveal mammary fat pad number 2 . A $0.1-\mathrm{ml}$ sample containing $10^{4}$ tumors was injected into the mammary fat pad and the incision was closed with a wound clip. Tumor volume was measured once a week using an electronic caliper. The tumor volume was estimated using the formula of an ellipsoid (length $\times$ width $\times$ height $\times 0.5236$ ). All animals were treated humanely and in accordance with the guidelines of the Committee on the Care and Use of Laboratory Animals of the Institute of Animal Resources, National Research Council and Institutional Animal Care and Use Committee (IACUC) of Scott \& White Hospital. For each group 5 mice were used for statistical significance.

\section{Establishment of stable cell line}

For the construction of $\mathrm{HER}^{+} / \mathrm{ER}^{+} / \mathrm{PgR}^{+} 4 \mathrm{~T} 1$ cells (TPBC) the 550 bp rat human epidermal growth factor receptor 2 (HER2) (extracellular domain containing the herceptin domain) upstream primer (5'-GTCGAAGCTTATGGAGCTGGCGGCCTGG-3') and downstream primer (5'GACTGAATTCTTAGTTGATGGGGCACGG-3'), and the $311 \mathrm{bp}$ rat estrogen receptor (ER) upstream primer (5'-TGACTCTGCAGCAACAGCAT-3') and downstream primer (5'-GAGTTCTCAGATGGTGTTGG-3') and the 460 bp rat progesterone receptor (PgR) upstream primer (5'-AACTGGTTCCGCCACTCAT-3') and downstream primer (5'-AACTGGTTCCGCCACTCAT-3') were used and cloned into a pcDNA6.2/EmGFP construct according to the manufactures' instructions (Invitrogen). For stable transfection pcDNA6.2/EmGFP construct was linearized before transfection into 4T1 cells using Lipofectamine ${ }^{\mathrm{TM}}$ 2000 Reagent (Invitrogen). Similarly, for the construction of $\mathrm{HER}^{-} / \mathrm{ER}^{-} / \mathrm{PgR}^{-} 4 \mathrm{~T} 1$ cells (TNBC), the pcDNA6.2/ EmGFP vector alone was used. Forty-eight hours after transfection, cells were split and growth media containing DMEM supplemented with $10 \%$ FBS and $10 \mu \mathrm{g} / \mathrm{ml}$ Blasticidin (Invitrogen) was added. After 4 days Blasticidin-resistant colonies were identified and further propagated. Cells stably transfected with enhanced green fluorescent protein (eGFP) were further enriched for eGFP-positive populations by sorting using a BD FACSAria flow cytometer (BD Biosciences) equipped with a $488 \mathrm{~nm}$ argon laser. The emission filter for eGFP was set at 515-545 nm. The presence of HER2, PgR and ER in TPBC was confirmed by Western blot analysis and PCR. Pure TNBC cells were obtained after Flow Cytometry sorting for $\mathrm{ER}^{-} / \mathrm{PgR}^{-} 4 \mathrm{~T} 1$ cells.

\section{Limiting dilution transplantation assay}

After FACS sorting for 4T1wt, TNBC, TNBC-TICs, TPBC, TPBC-TICs expressing high levels of enhanced green fluorescence protein (eGFP), cells were washed once with ice-cold PBS and mixed in DMEM supplemented with 25\% Matrigel (BD Biosciences). Female BALB/c (6-8 weeks old) were lightly anesthetized and the fur was shaved over the lateral thorax and a 5-mmlong incision was made to reveal mammary fat pad number 2. A $0.1-\mathrm{ml}$ sample containing various concentrations of eGFP-bearing cells (500, 100, 50, 25 and 10) was injected into the mammary fat pad and the incision was closed with a wound clip. Confidence interval (95\%) for repopulating mammary cell frequency were calculated using ELDA, a software application for limiting dilution analysis (LDA) as previously described [34]. All animals were treated humanely and in accordance with the guidelines of the Committee on the Care and Use of Laboratory Animals of the Institute of Animal Resources, National Research Council and Institutional Animal Care and Use Committee (IACUC) of Scott \& White Hospital. For each group 5 mice were used for statistical significance.

\section{Live animal imaging}

Live animal imaging was achieved by measuring the spectral fluorescence images captured using the Maestro $^{\mathrm{TM}}$ in vivo imaging system (CRI, Woburn, MA). An excitation band pass filter from 445 to $490 \mathrm{~nm}$ and an emission filter over $515 \mathrm{~nm}$ were used. The tunable filter was automatically spaced in $10 \mathrm{~nm}$ increments from 500 to $720 \mathrm{~nm}$ while the camera captured fluorescence images at each wavelength with constant exposure. RGB (red-green-blue) color fluorescence images were synthesized from the spectral cube by mapping the spectral data into those color channels. All the fluorescence images obtained as RGB images were derived from the 
spectral datasets. Spectral unmixing was performed to segregate skin and hair auto fluorescence and to measure the true eGFP signal.

\section{Clonogenicity assay}

The ability of tumor cells to metastasize to distant organs was assessed using the clonogenicity assay as previously described [26,35]. Briefly, mice were sacrificed and lung tissue was aseptically removed, minced with trypsin, seeded in triplicate at 1,000 cells/per $60 \mathrm{~mm}^{3}$ petri-dish and incubated at $37^{\circ} \mathrm{C}$ in a $5 \% \mathrm{CO}_{2}$ air atmosphere. Ten to twelve days later, the plates were washed twice with PBS and colonies were stained with crystal violet and counted. The colonizing efficiency was scored and results were compared to those in vehicle-treated cells.

\section{Protein separation and western blot analysis}

Following various treatment protocols cells were washed once with complete medium, centrifuged and pellets lysed with $100 \mu \mathrm{l}$ of lysing buffer containing a cocktail of protease inhibitors (antipain, bestain, chymostatin, E64, pepstatin, phosphoramidon, pefabloc, ethylenediaminetetraacetic acid (EDTA), aprotinin; Complete Protease Inhibitor Cocktail Tablets ${ }^{\circledR}$, Roche Diagnostics). Cells were then incubated for $30 \mathrm{~min}$ on ice and sonicated (Brandson 1510) for $15 \mathrm{~min}$. The cell suspension was passed through a 26-gauge needle and protein quantification was performed using the Bradford method. Proteins were separated in a $10 \%$ sodium dodecyl sulfate polyacrylamide gel electrophoresis (SDS-PAGE) by carefully placing $30 \mu \mathrm{g}$ of protein in each lane. Polyvinylidene fluoride (PVDF) (Millipore) was used to transfer the proteins and the membrane blocked with 5\% skim milk (in TBS 1\% pH 7.4 and $0.01 \%$ Tween 20) and incubated for $1 \mathrm{~h}$ at room temperature with appropriate primary antibodies; anti-Hsp72/HspA1A and anti-Hsp73/ HspA8 (StressGen Biotechnologies, BC, Canada), or $\beta$ actin (Oncogene, San Diego, CA) with 1:1000 dilution. Blots were incubated $50 \mathrm{~min}$ at room temperature with $0.5 \mu \mathrm{g}$ of appropriate species matched anti-peroxidase and the reaction was detected using the Luminol reagent for chemiluminescence (Santa Cruz Biotechnology). The intensity of the bands were analyzed by densitometry with a video densitometer (Chemilmager ${ }^{\mathrm{TM}}$ 5500; Alpha Innotech, San Leandro, CA) using the AAB software (American Applied Biology).

\section{Flow cytometry and cell sorting}

For the isolation of TICs from TNBC and TPBC; $10^{7}$ cells were stained with anti-CD24-FITC (1:100, BD Transduction Labs), anti-CD44-PE (1:200, BD Transduction Labs) and anti-ALDH1-Alexa-Fluor-568 (1:100, Molecular Probes) under previously optimized conditions. Isotype controls (IgG) were used as negative controls. CD $24^{+} / \mathrm{CD} 44^{\text {high }} / \mathrm{ALDH}^{+}$and $\mathrm{CD} 24^{-} / \mathrm{CD} 44^{-} /$ ALDH1 $1^{-}$cells were sorted using a BD FACSort with a Lysys II software program (BD Biosciences). Individual cells were gated based on forward (FSC) and orthogonal scatter (SSC). Cell debris was excluded by raising the FSC-height photomultiplier (PMT) threshold. The PMT for FITC (FL1-height), PE (FL2-height) and Alexa-Fluor 568 (FL-3-height) was set on a logarithmic scale. The flow rate was adjusted to $<200$ cells/second. Post sorted cells were collected in cell culture medium containing $20 \%$ FBS and then washed and returned to $4 \mathrm{~T} 1$ complete medium; DMEM supplemented with $10 \%$ FBS and maintained at $37^{\circ} \mathrm{C}$ humidified atmosphere with $5 \% \mathrm{CO}_{2}$.

\section{Fluorescence microscopy}

Standard fluorescence microscopy was performed using an Olympus CKX41 microscope. A DP71 CCD camera was used to capture phase contrast and eGFP fluorescence images with DP71 image acquisition interface software (Olympus).

\section{Statistical analysis}

For comparisons between groups, Dunn multiple comparison tests and student $t$-test and one-way analysis of variance (ANOVA) were used in this study ( $\mathrm{p}$ values < 0.001 were considered significant).

\section{Results}

Development of mouse TNBC, TPBC and breast cancer Tumor-Initiating Cells (TICs)

To understand the molecular characteristics of TNBC, and determine the reason for its highly aggressive phenotype as compared to TPBC, we used the 4T1 breast adenocarcinoma mouse cell line as a model system, because tumor growth and metastatic spread of 4T1 cells very closely mimic human breast cancer and has the advantage of being able to be transplanted into immune competent recipients. To produce a population of TNBC cells, we transfected parental 4T1 cells with empty vector control and sorted for cells that do not express HER2, ER or PgR (HER2 $/ \mathrm{ER}^{-} / \mathrm{PgR}^{-}$) using flow cytometry and sorted to $>90 \%$ purity termed TNBC (Figure 1A; middle panels). Western blot analysis revealed that there was no significant increase in the HER2 expression in TNBC, as compared to parental 4T1 cells and no expression of either ER or PgR (Figure $1 \mathrm{~B}$; lane 2). We then constructed a population of $4 \mathrm{~T} 1$ breast cancer cells to mimic the TPBC phenotype in humans, and that are phenotypically $\mathrm{HER} 2^{+} / \mathrm{ER}^{+} / \mathrm{PgR}^{+}$. The rationale for creating a TPBC $4 \mathrm{~T} 1$ cell line is to act as a relevant control for the TNBC $4 \mathrm{~T} 1$ cell line. This was achieved by stable transfection of parental 4T1 cells (Figure 1A; left panels) with the rat HER2, ER and PgR 
A
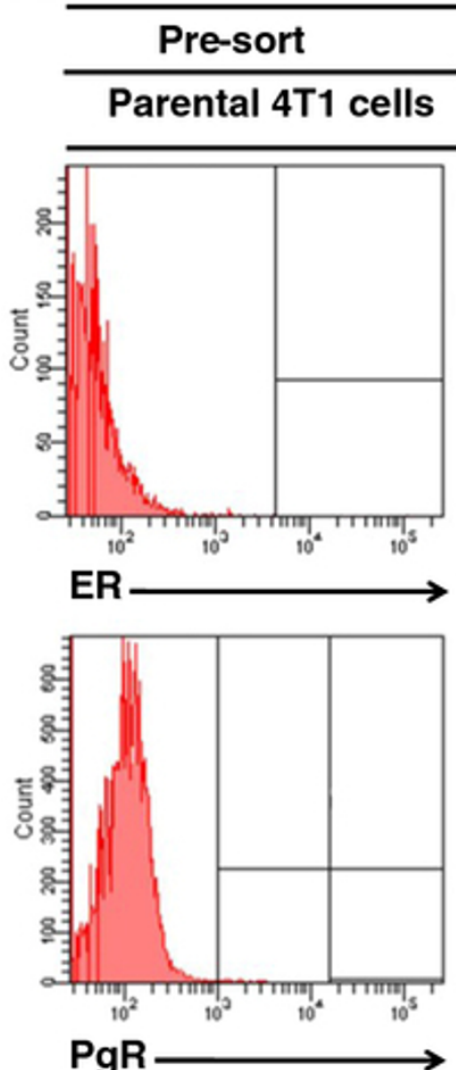

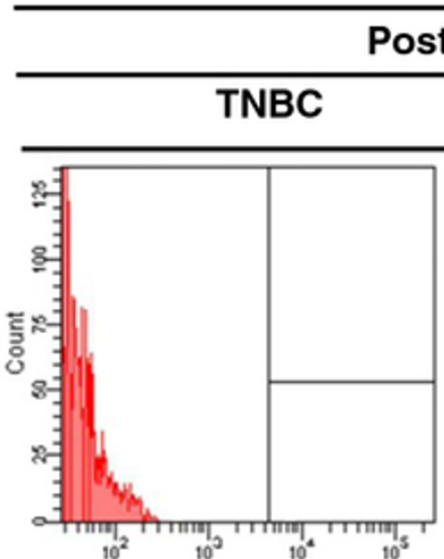

Post-sort

ER

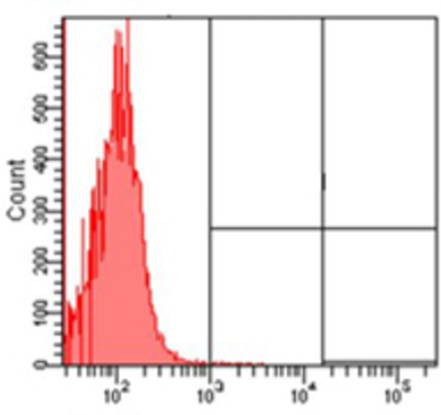

$\mathrm{PgR}$

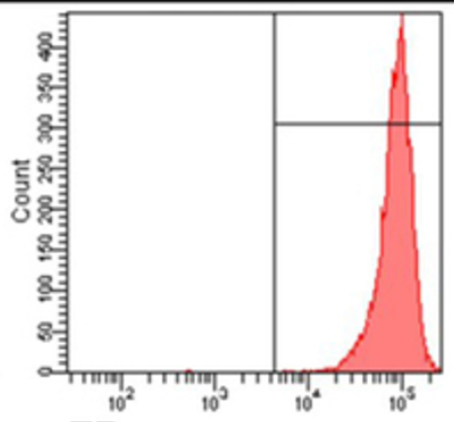

ER

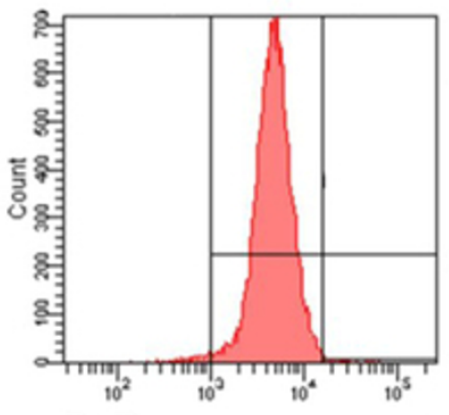

PgR

B

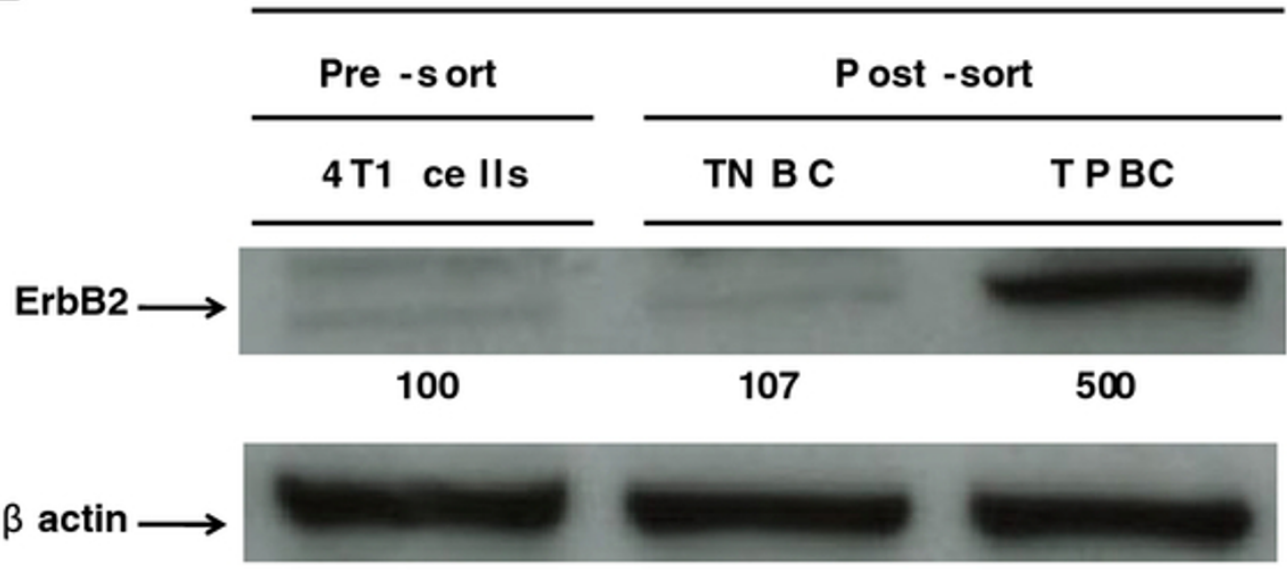

Figure 1 Transfection of rat HER2, ER and PgR genes into 4T1 cells produces a population of TNBC and TPBC. (A) Parental 4T1 cells $\left(10^{6}\right)$, TNBC $\left(10^{6}\right)$, or TPBC $\left(10^{6}\right)$ were placed on ice and stained with anti-ER-FITC (top panels) or anti-PgR-PE (bottom panels). The surface intensity for these antibodies were analyzed by flow cytometry using a FACSort with a Lysys II software program (Becton \& Dickinson). Individual cells were gated based on forward (FSC) and orthogonal scatter (SSC). Cell debris was excluded by raising the FSC-height PMT threshold. Histograms are mean relative counts and are a representative experiment of three independently performed experiments with similar results. (B) Parental 4T1 cells $\left(10^{6}\right)$ (lane 1), TNBC $\left(10^{6}\right)$ (lane 2), or TPBC $\left(10^{6}\right)$ (lane 3) were lysed and the amount of ErbB2 (HER2) was determined by Western blot analysis using specific Mab as described in detail in the Materials and Methods section. $\beta$-actin was used as control for equal loading. The intensity of the bands were analyzed by densitometry with a video densitometer (Chemilmager ${ }^{\mathrm{TM}}$ 5500; Alpha Innotech, San Leandro, CA) using the AAB software (American Applied Biology). Data is a representative experiment from three independently performed experiments with similar results. 
genes to avoid non-specific immune responses. Cells were then sorted for high expression of ER and PgR by flow cytometry to $>90 \%$ purity and termed TPBC (Figure 1A; right panels). Western blot analysis revealed that the expression of HER2 (using anti-ErbB2 antibodies) in TPBC increased approximately 500\% above parental 4T1 cell levels (Figure 1B; lane 3).

To isolate a population of breast cancer tumor-initiating cells (TICs), we stained the TNBC (HER2 $/ \mathrm{ER}^{-} / \mathrm{PgR}^{-}$) and TPBC $\left(\mathrm{HER}^{+} / \mathrm{ER}^{+} / \mathrm{PgR}^{+}\right)$described above with antibodies known to differentiate breast cancer stem cells, including CD24 (a cell adhesion molecule), aldehyde dehydrogenase 1 (ALDH1; an enzyme that catalyses the oxidation of aldehydes) and CD44 (a cellsurface glycoprotein involved in cell-cell interactions, cell adhesion and migration). We uncovered two phenotypically distinct populations in each group; a population expressing $\mathrm{CD} 24^{+} / \mathrm{ALDH} 1^{+} / \mathrm{CD} 44^{\text {high }}$ and another population expressing $\mathrm{CD} 24^{-} / \mathrm{ALDH} 1^{-} / \mathrm{CD} 44^{\text {low }}$ cells (data not shown). Using flow cytometry sorting techniques, we sorted for $\mathrm{CD} 24^{+} / \mathrm{ALDH} 1^{+} / \mathrm{CD} 44^{\text {high }}$ cells to a > $90 \%$ purity (Figure 2 ).

Limiting dilution transplantation experiments were then performed to validate that the CD24 $4^{+}$ALDH1 ${ }^{+} / \mathrm{CD} 44^{\text {high }}$ cells do in fact have greater tumor initiating ability than $\mathrm{CD} 24^{+} / \mathrm{ALDH} 1^{-} / \mathrm{CD} 44^{\text {low }}$ cells. Our results demonstrated that $\mathrm{CD} 24^{+} / \mathrm{ALDH} 1^{+} / \mathrm{CD} 44^{\text {high }}$ cell fraction derived from TNBC and TPBC contain cells with a significantly greater ability to repopulate the breast tissue, as compared to $\mathrm{CD} 24^{+} / \mathrm{ALDH} 1^{-} / \mathrm{CD} 44^{\text {low }}$ cells derived from TNBC or TPBC (Table 1). The log-fraction plot of the limiting dilution model was generated using ELDA software for limiting dilution analysis (LDA) after fitting the data from Table 1. We demonstrated that the estimated $95 \%$ confidence intervals for repopulating mammary cells frequencies for CD24 +/ $\mathrm{ALDH} 11^{+} / \mathrm{CD} 44^{\text {high }}$ cells derived from TNBC and TPBC are 6.22 and 27.02, respectively, as compared to 3168.93 for $\mathrm{CD}_{24} 4^{+} / \mathrm{ALDH}^{-} / \mathrm{CD} 44^{\text {low }}$ cells derived from TNBC and TPBC (Table 2). The overall test for differences in stem cell frequencies between any of the groups gave a Chi-Square score of $142\left(\mathrm{p}=1.29 \times 10^{-}\right.$ $\left.{ }^{30}\right)$. The likelihood ratio test, which is designed to test whether the single-hit model is correct gave a ChiSquare of 0.00411 ( $\mathrm{p}=0.949$ ). The score test of heterogeneity, which is designed to test whether the different cultures (assays) have the same active cell proportion gave a Chi-Square of $0.728(\mathrm{p}=0.394)$. The slopes for $\mathrm{CD} 24^{+} / \mathrm{ALDH} 1^{+} / \mathrm{CD} 44^{\text {high }}$ cells derived from TNBC (green line) and TPBC (black lines), significantly differ from $\mathrm{CD} 24^{+} / \mathrm{ALDH} 1^{-} / \mathrm{CD} 44^{\text {low }}$ cells derived from either TNBC (blue line) or TPBC (red line), which overlap due to similar values (Figure 3 ). The estimated slope value is 1.02 , since the value is greater than 1 , this suggests a multi-hit model in which two or more cells are synergistically required to produce a positive response (Figure $3)$. We therefore termed the $\mathrm{CD} 24^{+} / \mathrm{ALDH} 1^{+} / \mathrm{CD} 44^{\text {high }}$ cells tumor-initiating cells (TICs). Thus, TICs derived from TNBC were designated TNBC-TICs and TICs derived from TPBC were designated TPBC-TICs.

\section{Mouse TNBC-TICs proliferates faster and metastasizes to a greater extent than TPBC-TICs or parental 4T1 wild type cells} We further demonstrated that CD24 $4^{+}$ALDH1 ${ }^{+} / \mathrm{CD} 44^{\text {high }}$ cells derived from TNBC (TNBC-TICs) proliferated approximately 7 -fold more than parental $4 \mathrm{~T} 1$ cells, and that TPBC-TICs and TNBC proliferated 2fold and 3-fold more than the parental 4T1 cells, respectively. We demonstrated that TPBC did not proliferated significantly more than the parental $4 \mathrm{~T} 1$ cells in vitro (Figure 4). To determine the clonogenic growth potential and migratory properties of the newly developed TICs, we implanted TICs into the breast pad of naïve female BALB/c mice and demonstrated that TNBCTICs developed tumors approximately 4-fold larger than parental 4T1 cells (Figure 5). We further demonstrated that TPBC and TNBC produced tumors 1.5-fold and 2.5 -fold larger than tumors developed by the parental $4 \mathrm{~T} 1$ cells (Figure 5). To negate the possibility that hematoxylin and eosin (H\&E) staining of lung tissues might inadvertently miss micro-metastasis, we used the clonogenicity assay on the lungs of isolated 21 days post tumor cell implantation and revealed that TNBC-TICs and TNBC developed approximately 5-fold and 2-fold more metastatic foci than the parental $4 \mathrm{~T} 1$ cells, respectively (data not shown). Interestingly, TPBC-TICs and TPBC did not produce significantly more metastatic foci than the parental 4T1 cells (Figure 6).

High levels of mouse HspB1 have been shown to be associated with increased tumor growth and high metastatic potential $[24,25,36]$. To determine if the increased metastatic potential exhibited by TNBC-TICs is associated with increased mouse HspB1expression, we probed the cells with mouse HspB1 and Hsp72/HspA1A after Western blot analysis and demonstrated that TNBC-TICs express $876 \%$ higher levels of mouse HspB1 $1,003 \%$ higher levels of Hsp72/HspA1A as compared to parental 4T1 cells (Figure 7).

\section{Discussion}

This study was undertaken to address a critical need in TNBC research; develop a model system which can be used to elucidate the reason for the apparent highly aggressive phenotype of triple-negative breast cancer (TNBC). We have successfully developed four cell lines derived from the parental 4T1 breast adenocarcinoma mouse cell lines that can be used to study the pathogenesis and therapeutic treatment for TNBC. 

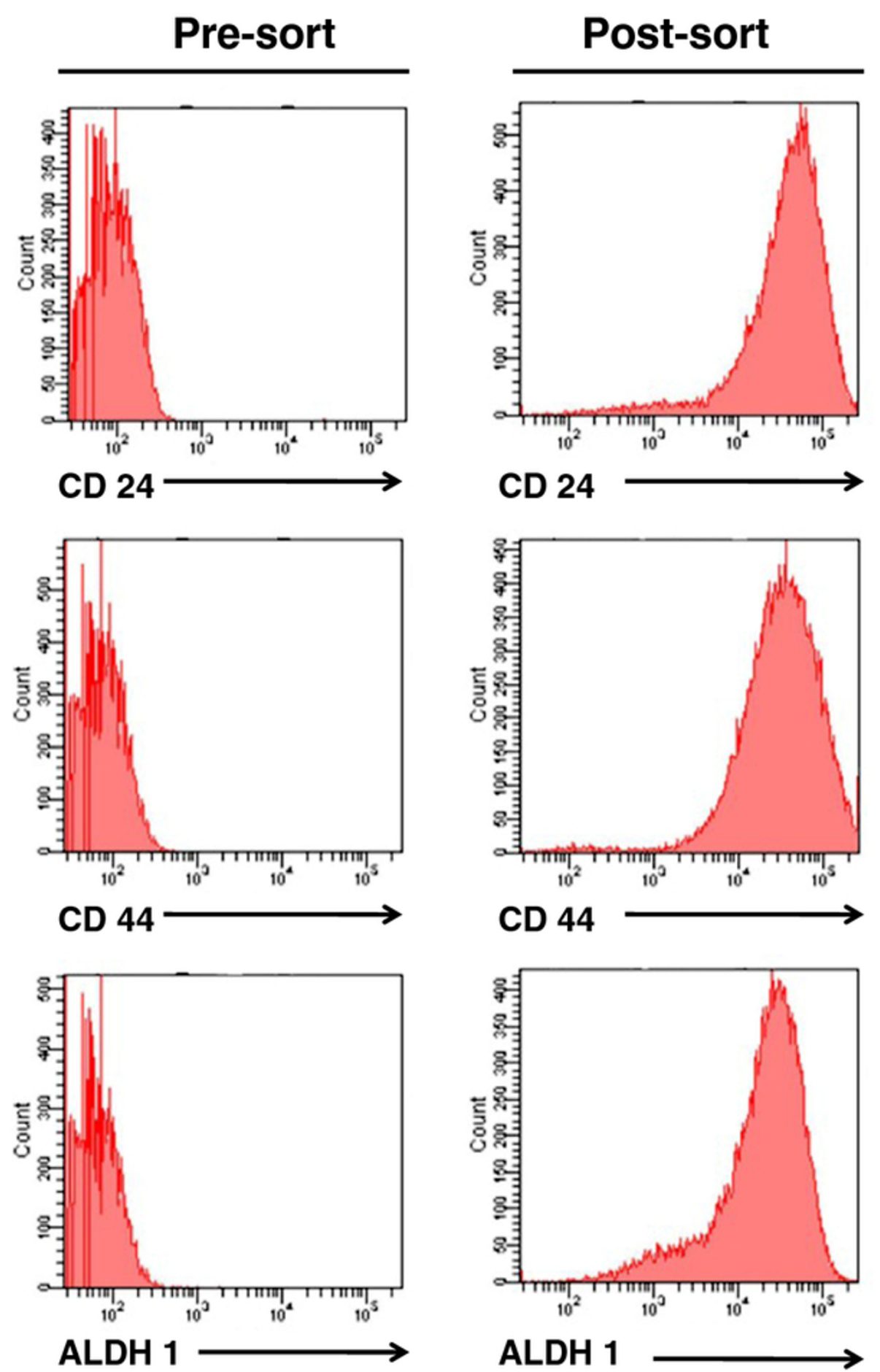

Figure 2 Selection of triple-negative breast cancer-cancer stem cells (TNBC-TICs). CD24, CD44 and ALDH1 antibodies were used to isolate a population of breast cancer tumor-initiating cells (TICs) from TNBC. TNBC $\left(10^{6}\right)$ were placed on ice and stained with anti-CD24-FITC (top panels), anti-CD44-PE (middle panels) and anti-ALDH1 (bottom panels). Cells were sorted using a FACSort with a Lysys II software program (Becton \& Dickinson). Individual cells were gated based on forward (FSC) and orthogonal scatter (SSC). Cell debris was excluded by raising the FSC-height PMT threshold. Histograms are mean relative counts and are a representative experiment of three independently performed experiments with similar results. 
Table 1 TNBC-TICs exhibit a greater clonogenic growth potential as compared to TNBC, TPBC-TICs, TPBC or parental 4T1 cells

\begin{tabular}{|c|c|c|}
\hline Cell type $^{1}$ & $\begin{array}{l}\text { Number } \\
\text { of cells } \\
\text { transplanted }\end{array}$ & $\begin{array}{l}\text { Fraction } \\
\text { of mice } \\
\text { with tumors }\end{array}$ \\
\hline \multicolumn{3}{|l|}{ TPBC-derived: } \\
\hline $\mathrm{CD} 24^{+} / \mathrm{ALDH}^{+} / \mathrm{CD} 44^{\text {high }}$ & 500 & $5 / 5$ \\
\hline $\mathrm{CD} 24^{+} / \mathrm{ALDH}^{+} / \mathrm{CD} 44^{\text {high }}$ & 100 & $5 / 5$ \\
\hline $\mathrm{CD} 24^{+} / \mathrm{ALDH}^{+} / \mathrm{CD} 44^{\text {high }}$ & 50 & $4 / 5$ \\
\hline $\mathrm{CD} 24^{+} / \mathrm{ALDH}^{+} / \mathrm{CD} 44^{\text {high }}$ & 25 & $2 / 5$ \\
\hline $\mathrm{CD} 24^{+} / \mathrm{ALDH}^{+} / \mathrm{CD} 44^{\text {high }}$ & 10 & $3 / 5$ \\
\hline \multicolumn{3}{|l|}{ TPBC-derived: } \\
\hline $\mathrm{CD} 24^{+} / \mathrm{ALDH}^{2} / \mathrm{CD} 44^{\text {low }}$ & 500 & $1 / 5$ \\
\hline $\mathrm{CD} 24^{+} / \mathrm{ALDH}^{-} / \mathrm{CD} 44^{\text {low }}$ & 100 & $0 / 5$ \\
\hline $\mathrm{CD} 24^{+} / \mathrm{ALDH}^{-} / \mathrm{CD} 44^{\mathrm{low}}$ & 50 & $0 / 5$ \\
\hline $\mathrm{CD} 24^{+} / \mathrm{ALDH}^{-} / \mathrm{CD} 44^{\text {low }}$ & 25 & $0 / 5$ \\
\hline $\mathrm{CD} 24^{+} / \mathrm{ALDH}^{-} / \mathrm{CD} 44^{\text {low }}$ & 10 & $0 / 5$ \\
\hline \multicolumn{3}{|l|}{ TNBC-derived: } \\
\hline $\mathrm{CD} 24^{+} / \mathrm{ALDH}^{+} / \mathrm{CD} 44^{\text {high }}$ & 500 & $5 / 5$ \\
\hline $\mathrm{CD} 24^{+} / \mathrm{ALDH}^{+} 1^{+} / \mathrm{CD}_{4} 4^{\text {high }}$ & 100 & $5 / 5$ \\
\hline $\mathrm{CD} 24^{+} / \mathrm{ALDH}^{+} / \mathrm{CD} 44^{\text {high }}$ & 50 & $5 / 5$ \\
\hline $\mathrm{CD} 24^{+} / \mathrm{ALDH}^{+} 1^{-\mathrm{CD}} 44^{\text {high }}$ & 25 & $5 / 5$ \\
\hline $\mathrm{CD} 24^{+} / \mathrm{ALDH}^{+}{ }^{+} / \mathrm{CD} 44^{\text {high }}$ & 10 & $4 / 5$ \\
\hline \multicolumn{3}{|l|}{ TNBC-derived: } \\
\hline $\mathrm{CD} 24^{+} / \mathrm{ALDH}^{-} / \mathrm{CD} 44^{\text {low }}$ & 500 & $1 / 5$ \\
\hline $\mathrm{CD} 24^{+} / \mathrm{ALDH}^{-} / \mathrm{CD} 44^{\mathrm{low}}$ & 100 & $0 / 5$ \\
\hline $\mathrm{CD} 24^{+} / \mathrm{ALDH}^{-} / \mathrm{CD} 44^{\text {low }}$ & 50 & $0 / 5$ \\
\hline $\mathrm{CD} 24^{+} / \mathrm{ALDH}^{-} / \mathrm{CD} 44^{\text {low }}$ & 25 & $0 / 5$ \\
\hline $\mathrm{CD} 24^{+} / \mathrm{ALDH}^{-} / \mathrm{CD} 44^{\text {low }}$ & 10 & $0 / 5$ \\
\hline
\end{tabular}

${ }^{1}$ Tumor cells derived from TPBC or TNBC cells were stably transfected with eGFP using the lentivirus transduction technique as described in detail in the Methods section

${ }^{2}$ Twenty-one days post tumor cell transplantation into the mammary pad of naïve female BALB/c mice, animals were scarified and eGFP signal from the tumors were measured using the Maestro ${ }^{\mathrm{TM}}$ in vivo imaging system (CRI), and spectral unmixing was performed to segregate skin and hair auto fluorescence and to measure the true eGFP signal, as described in detail in the Methods section. Data is the fraction of mice with tumors $(n=5)$

Table 2 Confidence interval (95\%) for repopulating mammary cell frequency

\begin{tabular}{|c|c|c|c|}
\hline \multirow[t]{2}{*}{ Cell type } & \multicolumn{3}{|c|}{$\begin{array}{l}\text { Confidence intervals for } 1 /(\mathrm{TICs} \\
\text { frequency) })^{1}\end{array}$} \\
\hline & Lower & Estimate & Upper \\
\hline \multicolumn{4}{|l|}{ TPBC-derived: } \\
\hline $\mathrm{CD} 24^{+} / \mathrm{ALDH}^{+} / \mathrm{CD} 44^{\text {high }}$ & 51.0 & 27.02 & 14.4 \\
\hline $\mathrm{CD} 24^{+} / \mathrm{ALDH}^{-} / \mathrm{CD} 44^{\text {low }}$ & 22124.7 & 3168.93 & 454.3 \\
\hline \multicolumn{4}{|l|}{ TNBC-derived: } \\
\hline $\mathrm{CD} 24^{+} / \mathrm{ALDH}^{+} / \mathrm{CD} 44^{\text {high }}$ & 14.9 & 6.22 & 2.8 \\
\hline $\mathrm{CD} 24^{+} / \mathrm{ALDH}^{-} / \mathrm{CD} 44^{\text {low }}$ & 22124.7 & 3168.93 & 454.3 \\
\hline
\end{tabular}

${ }^{1}$ Confidence interval (95\%) for repopulating mammary cell frequency for the data in Table 1. Data were generated using ELDA, a software application for limiting dilution analysis (LDA) as previously described [34]

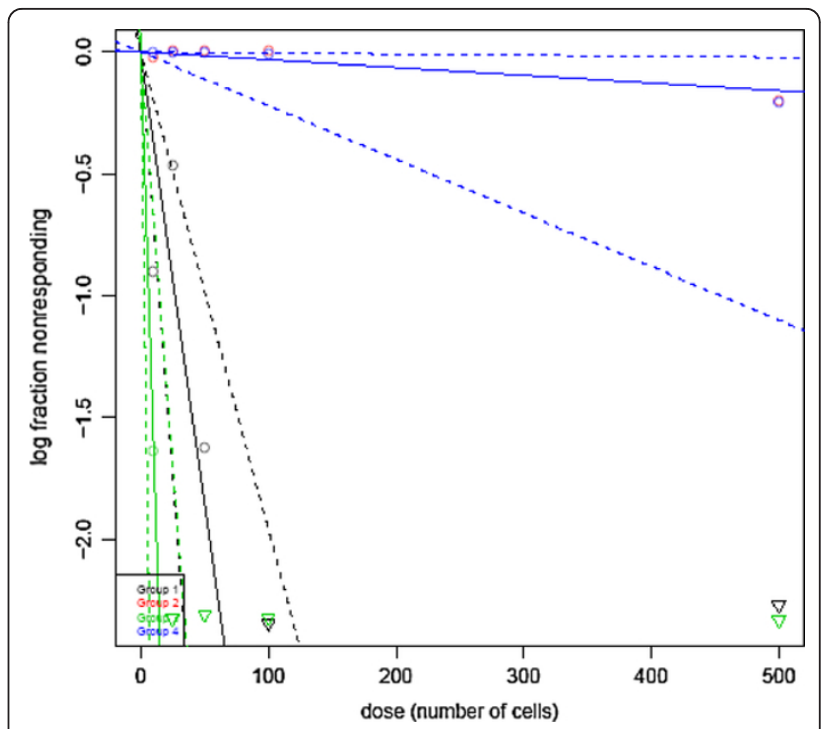

Figure $3 \mathrm{CD} 24^{+} / \mathrm{ALDH}^{+} / \mathrm{CD} 44^{\text {high }}$ identifies a population of TICs in both TNBC and TPBC cell fractions. The log-fraction plot of the limiting dilution model has been generated using ELDA software for limiting dilution analysis (LDA) after fitting the data from Table 1. The slopes for $\mathrm{CD}_{2} 4^{+} / \mathrm{ALDH}^{+} / \mathrm{CD} 44^{\text {high }}$ cells derived from TNBC (green line), $\mathrm{CD} 24^{+} / \mathrm{ALDH1}^{-} / \mathrm{CD} 44^{\text {low }}$ cells derived from TNBC (blue line), CD24 ${ }^{+} / \mathrm{ALDH1}^{+} / \mathrm{CD} 44^{\text {high }}$ cells derived from TPBC (black line), CD24 $+/ \mathrm{ALDH} 1^{1 / \mathrm{CD}} 44^{\text {low }}$ cells derived from TPBC (red line), is the log-active cell fraction. The dotted lines give the $95 \%$ confidence interval.

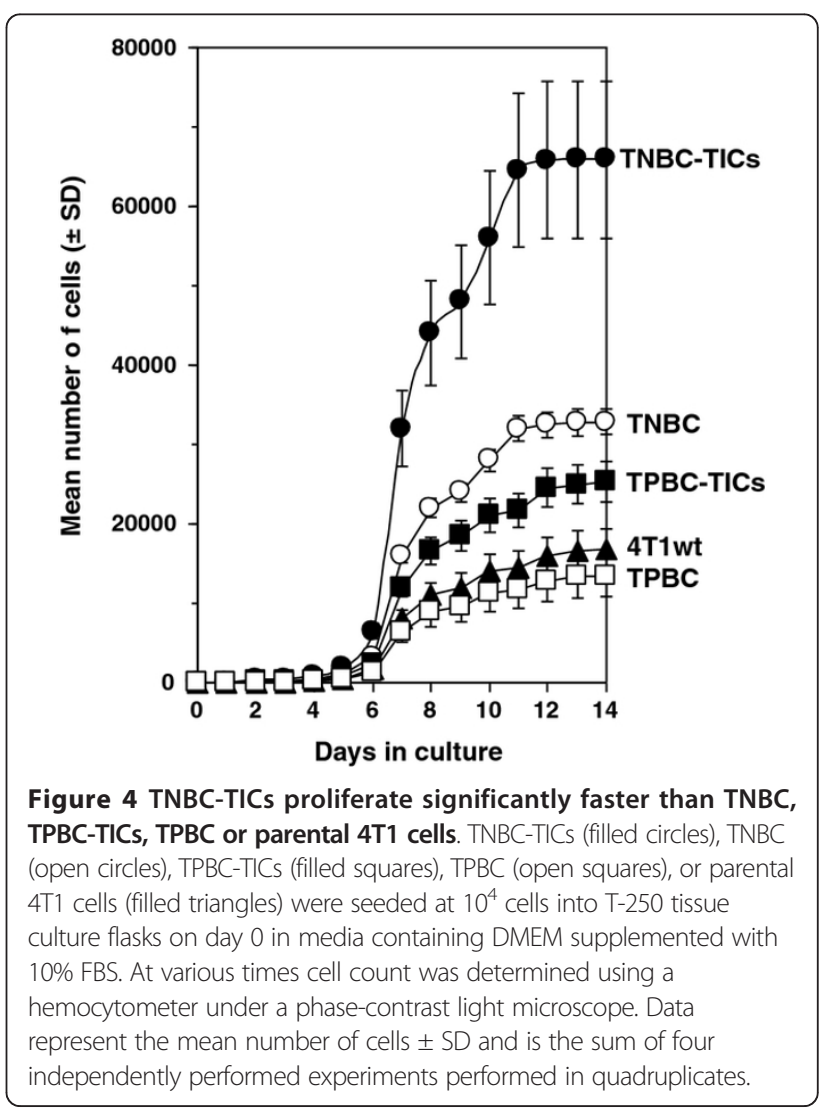




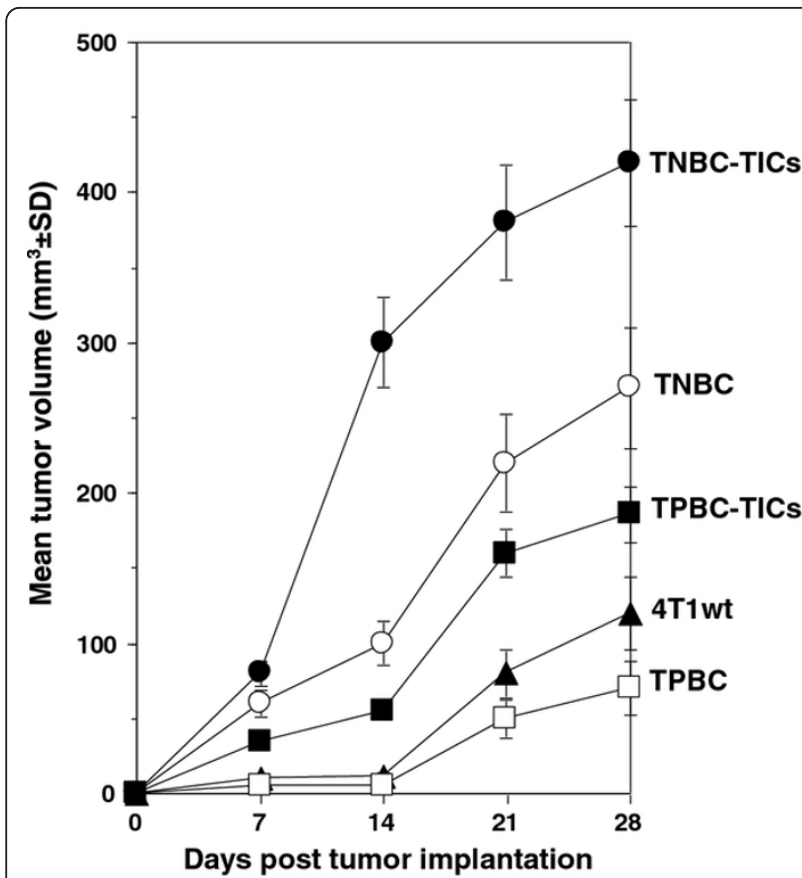

Figure 5 Tumors from TNBC-TICs grow significantly larger than TNBC, TPBC-TICs, TPBC or parental 4T1 cells. Implantation of TNBC-TICs into female BALB/C mice resulted in larger tumors than TNBC, TPBC-TICs, TPBC or parental 4T1 cells. TNBC-TICs (filled circles), TNBC (open circles), TPBC-TICs (filled squares), TPBC (open squares), or parental $4 \mathrm{~T} 1$ cells (filled triangles) $10^{4}$ cells were implanted into the left breast pad of female BALB/c mice (6-8 weeks old) and tumor growth was measured using an electronic calipher. Data are mean tumor volume $\mathrm{mm}^{3} \pm \mathrm{SD}$ and are the sum of three independently performed experiments with five mice per group.

Limiting dilution transplantation experiments validate that $\mathrm{CD} 24^{+} / \mathrm{ALDH}^{+} / \mathrm{CD} 44^{\text {high }}$ cells have a significantly greater tumor initiating ability than $\mathrm{CD} 24^{+} / \mathrm{ALDH} 1^{-} /$ CD44 ${ }^{\text {low }}$ cells (Tables 1 and 2). In addition, 95\% confidence intervals for repopulating mammary cells frequencies clearly demonstrated that $\mathrm{CD} 24^{+} / \mathrm{ALDH} 1^{+} / \mathrm{CD} 44^{\text {high }}$ cells derived from TNBC and TPBC have a greater repopulating ability than $\mathrm{CD} 24^{+} / \mathrm{ALDH} 1^{-} / \mathrm{CD} 44^{\text {low }}$ cells derived from TNBC and TPBC (Table 2), and is confirmed by $\log$-fraction plot of the limiting dilution model has been generated using ELDA software (Figure 3). Interestingly, $\mathrm{CD} 24^{+} / \mathrm{ALDH} 1^{+} / \mathrm{CD} 44^{\text {high }}$ cells derived from TNBC (TNBC-TICs) were approximately 4-fold more efficient than $\mathrm{CD} 24^{+} / \mathrm{ALDH} 1^{+} / \mathrm{CD} 44^{\text {high }}$ cells derived from TPBC (TPBC-TICs) (Table 2). The exact reason for this difference is currently under investigation in our laboratory (Kaur et al., in preparation). However, the data showing that TNBC-TICs exhibit classical signs of aggressive phenotype shown by human TNBC including increased tumor growth (Figure 5) and enhanced metastatic potential (Figure 6), led us to hypothesize that the differential expression of mouse HspB1 and

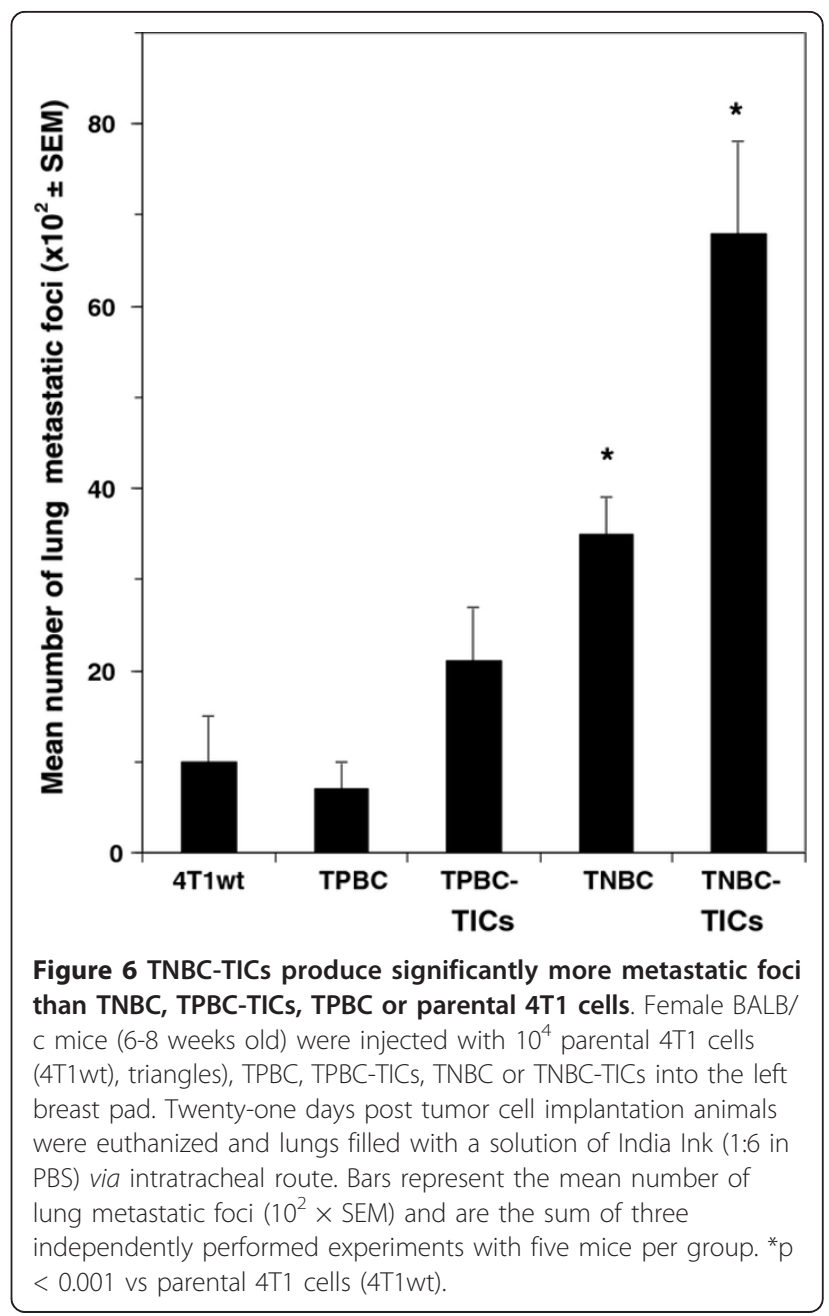

Hsp72/HspA1A, might be a possible explanation (Figure 7). We demonstrated that TNBC-TICs express significantly higher levels of mouse HspB1 and Hsp72/ HspA1A than TNBC, TPBC, TPBC-TICs or parental 4T1 cells (Figure 7). This data is in agreement with previous findings that elevated levels of mouse and human HspB1 promotes the progression of tumor to more malignant phenotypes $[16,24,25,37]$, and that elevated human HspB1 expression in tumors correlated with shorter disease free survival and recurrence in nodenegative breast cancer $[21,22]$. Our previous studies demonstrated that selection of 4T1 cells based on the expression of mouse HspB1 selects a particular phenotype with increased metastatic potential [25]. Further studies have demonstrated that increased metastatic potential of $4 \mathrm{~T} 1$ cells expressing high levels of mouse HspB1 can be abrogated by suppressing the expression of mouse HspB1 using small interfering RNA (siRNA) directed against the mouse $h s p b 1$ gene [24]. Nagaraja et al. recently reported that tumors with high levels of HspB1 are able to evade the immune system and rapidly 


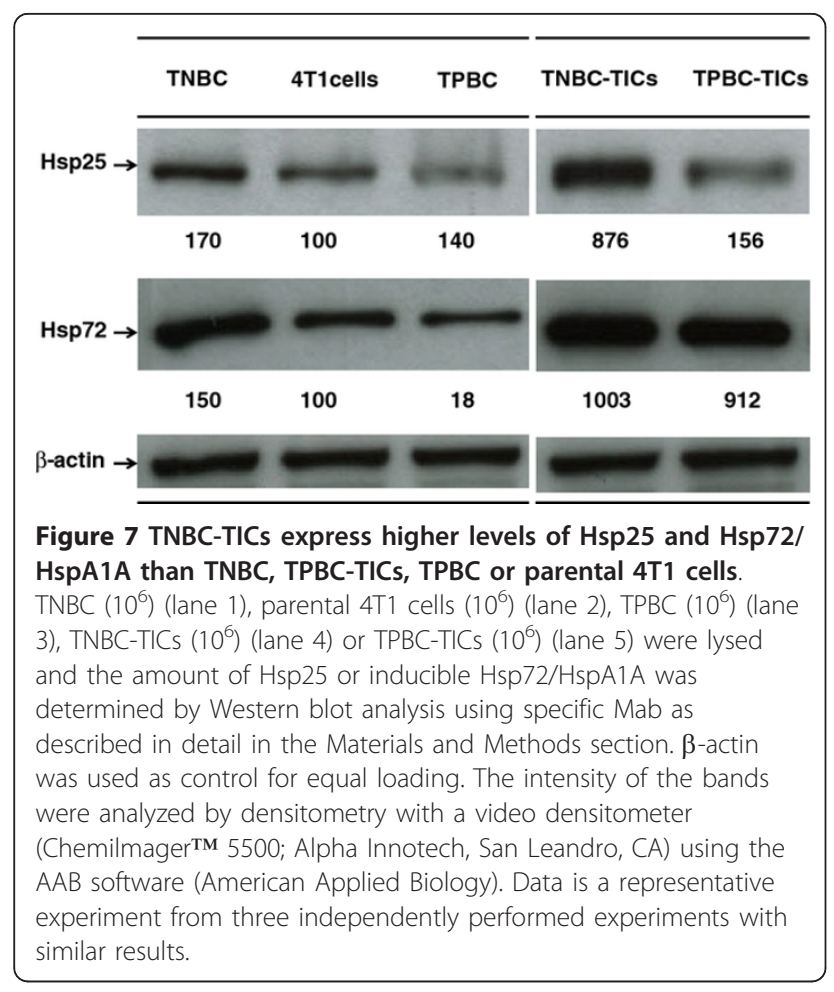

metastasize, in part, due to $\mathrm{HspB} 1$ acting as a repressor of proteasome function, which in turn results in insufficient presentation of tumor-associated antigens on the surface of tumors and a lack of recognition by $\mathrm{CD} 8^{+}$ cytotoxic T lymphocytes (CTL) [36]. These authors demonstrated that short term silencing of HspB1 using siRNA or permanent silencing using lentivirus-RNAi technology enhanced proteasome activity, abrogated metastatic potential, induced the regression of established breast tumors by tumor-specific $\mathrm{CD}^{+} \mathrm{T}$ cells and stimulated long-lasting memory responses [36].

Our study suggests that $\mathrm{CD} 24^{+} / \mathrm{ALDH} 1^{+} / \mathrm{CD} 44^{\text {high }}$ identifies TICs in both TNBC and TPBC cell fractions, TNBC-TICs and TPBC-TICs respectively. These cells clearly exhibit ability to aggressively repopulate the mammary tissue of mice in limiting dilution transplantation assays (Tables 1, 2 and Figure 3). The expression of aldehyde dehydrogenase 1 (ALDH1) a marker associated with cancer stem cell-like or TICs features, was significantly more common in $\mathrm{ER}^{-}$tumors. ALDH1 $1^{+}$cells were the least frequent in luminal $\mathrm{A}$ and $\mathrm{B}$ tumors compared to basal-like and HER $2^{+}$subtypes, correlating with a recent study in breast cancer cell lines [38]. CD44 +/CD24- cells and ALDH1 ${ }^{+}$cells were more frequently found in the basal-like than in luminal subtypes, however, $\mathrm{CD} 44^{+} / \mathrm{CD} 24^{-}$cells but not $\mathrm{ALDH} 1^{+}$cells were less common in $\mathrm{HER}_{2}{ }^{+}$than in basal-like cases. In normal breast tissue, $\mathrm{CD} 44^{+} / \mathrm{CD} 24^{-}$cells were limited to the basal layer whereas $\mathrm{ALDH} 1^{+}$cells were found in both basal and luminal compartments suggesting that ALDH might be a marker of both bipotential mammary epithelial stem cells and luminal lineage committed progenitors. The difference in the relative frequency of $\mathrm{CD} 44^{+} / \mathrm{CD} 24^{-}$and $\mathrm{ALDH} 1^{+}$cells between basal-like and $\mathrm{HER}^{+}{ }^{+}$tumor subtypes may reflect their distinct cell-oforigin or the alteration of stem cell-like gene expression programs due to tumor subtype-specific transforming events [39]. All markers identifying cancer stem cells are surface markers such as epithelial cell adhesion molecule (EpCAM), CD44, CD24, CD133 and C-X-C chemokine receptor type 4 (CXCR4) definitely expressed on the normal stem cells at the same time and apparently changing during cancer stem cell development. Rasheed et al. reported that ALDH could potentially be an endogenous marker for pancreatic TICs after experiments demonstrated significant clonogenic growth potential and migratory properties in vitro and in vivo [40]. In addition, these authors detected 90/269 $\mathrm{ALDH}^{+}$tumors in primary surgical specimens, and verified that their presence was associated with worse survival [40].

Previous studies clearly demonstrated that the high expression of human HspB1 in tumors correlates with increased tumor growth and enhanced metastatic potential [41]. In addition, the high surface expression of mouse HspB1 on 4T1 tumors significantly increases their ability to grow within the abdominal breast gland and to successfully metastasize and colonize the lungs and the interaction between host effector cells and tumors expressing high levels of surface-bound HspB1 results in abrogation and/or deactivation of host anti-tumor responses [25,37,41-43]. The rational for this study is that triple-negative breast cancer (TNBC) is as a type of breast cancer that has been described to be more aggressive than other kinds of breast cancer [4,44-48]. We hypothesized that a possible mechanism by which TNBC exhibit increased aggression and resistance to chemotherapy as compared to other cancers is, in part, due to the high expression of mouse and human HspB1.

\section{Conclusions}

In conclusion, these studies suggest that these cell lines could provide an important preclinical model for the characterization and effective targeting of cancer stem cells or TICs, and to help further our understanding of the aggressive nature of TNBC found in humans. This is significant because TNBC although slightly responsive to chemotherapy are significantly more difficult to treat and generally insensitive to most available hormonal or targeted therapeutic agents than other kinds of breast cancer. The cell lines described in this study will allow for a better understanding of the reason for this aggressive nature and will pave the way for the design of more effective therapeutics. 


\section{Abbreviations}

ALDH1: Aldehyde dehydrogenase 1; BRACA1: Breast cancer 1 early onset: CSC: Cancer stem cells; CTL: Cytotoxic T lymphocytes; CXCR4: C-X-C chemokine receptor type 4; EMT: Epithelial mesenchymal transition; eGFP: Enhanced green fluorescence protein; EpCAM: Epithelial cell adhesion molecule; ER: Endoplasmic reticulum; PgR: Progesterone receptor; HER2: Human epidermal growth factor receptor 2; HSP: Heat shock proteins; hsp: Heat shock protein gene; Hsp25/HspB1: Mouse twenty-five kDa heat shock protein; Hsp27/HspB1: Human twenty-seven kDa heat shock protein; Hsp72/ HspA1A: Seventy-two kDa heat shock protein; LDA: Limiting dilution analysis; MHC: Major histocompatibility complex; NK: Natural killer; RNAi: Interference ribonucleic acid; siRNA: Small interference ribonucleic acid; TICs: Tumorinitiating cells; TNBC: Triple-negative breast cancer; TPBC: Triple-positive breast cancer

\section{Acknowledgements}

We thank Princess Bempong, Shahrum Lillard and Viraj Mehta for expert technical assistance and the Scott \& White Flow Cytometry Core Facility for help with flow cytometry. This work was supported in part by Scott \& White Memorial Hospital and Clinic Research Advancement Awards (to PK, GMN and HZ); Scott \& White Memorial Hospital and Clinic, the Texas A\&M Health Science Center College of Medicine, the Central Texas Veterans Health Administration and an Endowment from the Cain Foundation (to AA).

\section{Author details}

'Department of Pathology, Scott \& White Memorial Hospital and Clinic and the Texas A\&M Health Science Center, College of Medicine, Temple, TX 76504, USA. ${ }^{2}$ Department of Medicine, Scott \& White Memorial Hospital and Clinic and the Texas A\&M Health Science Center, College of Medicine, Temple, TX 76508, USA. ${ }^{3}$ Department of Surgery, Makerere University, P. O. Box 7072, Kampala, Uganda. ${ }^{4}$ Department of Radiation Oncology, MD Anderson Cancer Center, 1515 Holcombe Boulevard, Houston, TX, USA. ${ }^{5}$ Division of Investigative Pathology, Scott \& White Memorial Hospital and Clinic and The Texas A\&M Health Science Center College of Medicine, 1901 South 1st Street, Building 205, Temple, TX 76504, USA.

\section{Authors' contributions}

AA conceived and designed the experiments. PK, GMN and $\mathrm{HZ}$ performed the experiments. PK, GMN, HZ, DG, MG, SK and AA analyzed the data. DG, $M G$, SK and AA contributed reagents/materials/analysis tools. PK and AA wrote the paper. All authors read and approved the final manuscript.

\section{Competing interests}

The authors declare that they have no competing interests.

Received: 11 September 2011 Accepted: 27 March 2012

Published: 27 March 2012

\section{References}

1. Burness ML, Grushko TA, Olopade Ol: Epidermal growth factor receptor in triple-negative and basal-like breast cancer: promising clinical target or only a marker? Cancer J 2010, 16(1):23-32.

2. Seal MD, Chia SK: What is the difference between triple-negative and basal breast cancers? Cancer J 2010, 16(1):12-16.

3. Hugh J, Hanson J, Cheang MC, Nielsen TO, Perou CM, Dumontet C, Reed J, Krajewska M, Treilleux I, Rupin M, et al: Breast cancer subtypes and response to docetaxel in node-positive breast cancer: use of an immunohistochemical definition in the BCIRG 001 trial. J Clin Oncol 2009, 27(8):1168-1176.

4. Dent R, Trudeau M, Pritchard KI, Hanna WM, Kahn HK, Sawka CA, Lickley LA, Rawlinson E, Sun P, Narod SA: Triple-negative breast cancer: clinical features and patterns of recurrence. Clin Cancer Res 2007, 13(15 Pt 1):4429-4434.

5. Nofech-Mozes S, Trudeau M, Kahn HK, Dent R, Rawlinson E, Sun P, Narod SA, Hanna WM: Patterns of recurrence in the basal and non-basal subtypes of triple-negative breast cancers. Breast Cancer Res Treat 2009, 118(1):131-137.

6. Sorlie T, Tibshirani R, Parker J, Hastie T, Marron JS, Nobel A, Deng S, Johnsen H, Pesich R, Geisler S, et al: Repeated observation of breast tumor subtypes in independent gene expression data sets. Proc Natl Acad Sci USA 2003, 100(14):8418-8423.
7. Christiansen JJ, Rajasekaran AK: Reassessing epithelial to mesenchymal transition as a prerequisite for carcinoma invasion and metastasis. Cancer Res 2006, 66(17):8319-8326.

8. Thiery JP, Sleeman JP: Complex networks orchestrate epithelialmesenchymal transitions. Nat Rev Mol Cell Biol 2006, 7(2):131-142.

9. Lee KM, Han W, Kim JB, Shin I, Ko E, Park IA, Lee DS, Oh K, Noh DY: The $\mathrm{CD} 49 \mathrm{~d}+$ /high subpopulation from isolated human breast sarcoma spheres. Int J Oncol 2012, 40(3):665-672.

10. Blackburn JS, Liu S, Langenau DM: Quantifying the frequency of tumorpropagating cells using limiting dilution cell transplantation in syngeneic zebrafish. J Vis Exp: JOVE 2011, 53:2790.

11. Herschkowitz Jl, Zhao W, Zhang M, Usary J, Murrow G, Edwards D, Knezevic J, Greene SB, Darr D, Troester MA, et al: Comparative oncogenomics identifies breast tumors enriched in functional tumorinitiating cells. Proc Natl Acad Sci USA 2012, 109(8):2778-2783.

12. Reya T, Morrison SJ, Clarke MF, Weissman IL: Stem cells, cancer, and cancer stem cells. Nature 2001, 414(6859):105-111.

13. Hennessy BT, Gonzalez-Angulo AM, Stemke-Hale K, Gilcrease MZ, Krishnamurthy S, Lee JS, Fridlyand J, Sahin A, Agarwal R, Joy C, et al: Characterization of a naturally occurring breast cancer subset enriched in epithelial-to-mesenchymal transition and stem cell characteristics. Cancer Res 2009, 69(10):4116-4124.

14. Egeblad M, Werb Z: New functions for the matrix metalloproteinases in cancer progression. Nat Rev Cancer 2002, 2(3):161-174.

15. Soldes OS, Kuick RD, Thompson IA, Hughes SJ, Orringer MB, lannettoni MD, Hanash SM, Beer DG: Differential expression of Hsp27 in normal oesophagus, Barrett's metaplasia and oesophageal adenocarcinomas. $\mathrm{Br}$ J Cancer 1999, 79(3-4):595-603.

16. O'Neill PA, Shaaban AM, West CR, Dodson A, Jarvis C, Moore P, Davies MP, Sibson DR, Foster CS: Increased risk of malignant progression in benign proliferating breast lesions defined by expression of heat shock protein 27. Br J Cancer 2004, 90(1):182-188.

17. Rust W, Kingsley K, Petnicki T, Padmanabhan S, Carper SW, Plopper GE: Heat shock protein 27 plays two distinct roles in controlling human breast cancer cell migration on laminin-5. Mol Cell Biol Res Commun 1999, 1(3):196-202.

18. Ciocca DR, Lo Castro G, Alonio LV, Cobo MF, Lotfi H, Teyssie A: Effect of human papillomavirus infection on estrogen receptor and heat shock protein hsp27 phenotype in human cervix and vagina. Int J Gynecol Pathol 1992, 11(2):113-121.

19. Oesterreich S, Weng CN, Qiu M, Hilsenbeck SG, Osborne CK, Fuqua SA: The small heat shock protein hsp27 is correlated with growth and drug resistance in human breast cancer cell lines. Cancer Res 1993 53(19):4443-4448.

20. Yamamoto K, Okamoto A, Isonishi S, Ochiai K, Ohtake Y: Heat shock protein 27 was up-regulated in cisplatin resistant human ovarian tumor cell line and associated with the cisplatin resistance. Cancer Lett 2001, 168(2):173-181.

21. Storm FK, Mahvi DM, Gilchrist KW: Heat shock protein 27 overexpression in breast cancer lymph node metastasis. Ann Surg Oncol 1996, 3(6):570-573.

22. Thor A, Benz C, Moore D, Goldman E, Edgerton S, Landry J, Schwartz L, Mayall B, Hickey E, Weber LA: Stress response protein (srp-27) determination in primary human breast carcinomas: clinical, histologic, and prognostic correlations. J Natl Cancer Inst 1991, 83(3):170-178.

23. Vargas-Roig LM, Gago FE, Tello O, Aznar JC, Ciocca DR: Heat shock protein expression and drug resistance in breast cancer patients treated with induction chemotherapy. Int J Cancer 1998, 79(5):468-475.

24. Bausero MA, Bharti A, Page DT, Perez KD, Eng JW, Ordonez SL, Asea EE, Jantschitsch C, Kindas-Muegge I, Ciocca D, et al: Silencing the hsp25 gene eliminates migration capability of the highly metastatic murine 4T1 breast adenocarcinoma cell. Tumour Biol 2006, 27(1):17-26.

25. Bausero MA, Page DT, Osinaga E, Asea A: Surface expression of Hsp25 and Hsp72 differentially regulates tumor growth and metastasis. Tumour Biol 2004, 25(5-6):243-251.

26. Asea A, Ara G, Teicher BA, Stevenson MA, Calderwood SK: Effects of the flavonoid drug quercetin on the response of human prostate tumours to hyperthermia in vitro and in vivo. Int I Hyperthermia 2001, 17(4):347-356.

27. Calderwood SK, Asea A: Targeting HSP70-induced thermotolerance for design of thermal sensitizers. Int J Hyperthermia 2002, 18(6):597-608. 
28. Jaattela M: Programmed cell death: many ways for cells to die decently Ann Med 2002, 34(6):480-488

29. Farkas B, Hantschel M, Magyarlaki M, Becker B, Scherer K, Landthaler M, Pfister K, Gehrmann M, Gross C, Mackensen A, et al: Heat shock protein 70 membrane expression and melanoma-associated marker phenotype in primary and metastatic melanoma. Melanoma Res 2003, 13(2):147-152.

30. Asea A, Kabingu E, Stevenson MA, Calderwood SK: HSP70 peptide-bearing and peptide-negative preparations act as chaperokines. Cell Stress Chaperones 2000, 5(5):425-431.

31. Asea A, Kraeft SK, Kurt-Jones EA, Stevenson MA, Chen LB, Finberg RW, Koo GC, Calderwood SK: HSP70 stimulates cytokine production through a CD14-dependant pathway, demonstrating its dual role as a chaperone and cytokine. Nat Med 2000, 6(4):435-442.

32. Asea A, Rehli M, Kabingu E, Boch JA, Bare O, Auron PE, Stevenson MA, Calderwood SK: Novel signal transduction pathway utilized by extracellular HSP70: role of toll-like receptor (TLR) 2 and TLR4. J Biol Chem 2002, 277(17):15028-15034.

33. Basu S, Suto R, Binder RJ, Srivastava PK: Heat shock proteins as novel mediators of cytokine secretion by macrophages. Cell Stress Chaperones 1998, 3:11-16

34. Hu Y, Smyth GK: ELDA: extreme limiting dilution analysis for comparing depleted and enriched populations in stem cell and other assays. $J$ Immunol Methods 2009, 347(1-2):70-78.

35. Asea A, Mallick R, Lechpammer S, Ara G, Teicher BA, Fiorentino S, Stevenson MA, Calderwood SK: Cyclooxygenase inhibitors are potent sensitizers of prostate tumours to hyperthermia and radiation. Int J Hyperthermia 2001, 17(5):401-414.

36. Nagaraja GM, Kaur P, Neumann W, Asea EE, Bausero MA, Multhoff G, Asea A: Silencing hsp25/hsp27 Gene Expression Augments Proteasome Activity and Increases CD8+ T-Cell-Mediated Tumor Killing and Memory Responses. Cancer Prev Res (Phila) Dec 20 [Epub ahead of print] 2011.

37. Bausero MA, Asea A: Role of Hsp25/27 in metastatic spread of cancer cells. In Heat Shock Proteins in Cancer. Volume 2, edn. Edited by: Calderwood SK, Dordrecht Ciocca D. The Netherlands: Springer Publishers: 2007:131-140.

38. Charafe-Jauffret $E$, Ginestier C, lovino F, Wicinski J, Cervera N, Finetti P, Hur MH, Diebel ME, Monville F, Dutcher J, et al: Breast cancer cell lines contain functional cancer stem cells with metastatic capacity and a distinct molecular signature. Cancer Res 2009, 69(4):1302-1313.

39. Korkaya $H$, Paulson $A$, lovino $F$, Wicha MS: HER2 regulates the mammary stem/progenitor cell population driving tumorigenesis and invasion. Oncogene 2008, 27(47):6120-6130.

40. Rasheed ZA, Yang J, Wang Q, Kowalski J, Freed I, Murter C, Hong SM Koorstra JB, Rajeshkumar NV, He X, et al: Prognostic significance of tumorigenic cells with mesenchymal features in pancreatic adenocarcinoma. J Natl Cancer Inst 2010, 102(5):340-351.

41. Ciocca DR, Vargas-Roig LM: Hsp27 as a prognostic and predictive factor in cancer. Prog Mol Subcell Biol 2002, 28:205-218

42. Bausero MA, Bharti A, Page DT, Perez KD, Eng JW, Ordonez SL, Asea EE, Jantschitsch C, Kindas-Muegge I, Ciocca D, et al: Silencing the hsp25 gene eliminates migration capability of the highly metastatic murine $4 \mathrm{~T} 1$ breast adenocarcinoma cell. Tumour Biol 2005, 27(1):17-26.

43. Bausero MA, Gastpar R, Multhoff $G$, Asea A: Alternative mechanism by which IFN-gamma enhances tumor recognition: active release of heat shock protein 72. J Immunol 2005, 175(5):2900-2912.

44. Cleator S, Heller W, Coombes RC: Triple-negative breast cancer: therapeutic options. Lancet Oncol 2007, 8(3):235-244.

45. Dent R, Hanna WM, Trudeau M, Rawlinson E, Sun P, Narod SA: Pattern of metastatic spread in triple-negative breast cancer. Breast Cancer Res Treat 2009, 115(2):423-428

46. Liedtke C, Mazouni C, Hess KR, Andre F, Tordai A, Mejia JA, Symmans WF, Gonzalez-Angulo AM, Hennessy B, Green M, et al: Response to neoadjuvant therapy and long-term survival in patients with triplenegative breast cancer. J Clin Oncol 2008, 26(8):1275-1281.

47. Lin NU, Claus E, Sohl J, Razzak AR, Arnaout A, Winer EP: Sites of distant recurrence and clinical outcomes in patients with metastatic triplenegative breast cancer: high incidence of central nervous system metastases. Cancer 2008, 113(10):2638-2645.

48. Stockmans G, Deraedt K, Wildiers H, Moerman P, Paridaens R: Triplenegative breast cancer. Curr Opin Oncol 2008, 20(6):614-620.

\section{Pre-publication history}

The pre-publication history for this paper can be accessed here: http://www.biomedcentral.com/1471-2407/12/120/prepub

doi:10.1186/1471-2407-12-120

Cite this article as: Kaur et al.: A mouse model for triple-negative breast cancer tumor-initiating cells (TNBC-TICS) exhibits similar aggressive phenotype to the human disease. BMC Cancer 2012 12:120.

\section{Submit your next manuscript to BioMed Central and take full advantage of:}

- Convenient online submission

- Thorough peer review

- No space constraints or color figure charges

- Immediate publication on acceptance

- Inclusion in PubMed, CAS, Scopus and Google Scholar

- Research which is freely available for redistribution

Submit your manuscript at www.biomedcentral.com/submit
C Biomed Central 